\title{
WASF3 Gene
}

National Cancer Institute

\section{Source}

National Cancer Institute. WASF3 Gene. NCI Thesaurus. Code C138126.

This gene plays a role in signaling and cytoskeletal remodeling. 